\title{
BANTUAN HUKUM BAGI PELAKU USAHA KECIL DAN MENENGAH DI KECAMATAN SELAJAMBE, KUNINGAN
}

\author{
Suwari Akhmaddhian, Bias Lintang Dialog, Dikha Anugrah dan Yani Andriyani \\ Fakultas Hukum, Universitas Kuningan, Kuningan, Indonesia \\ Email: suwari_akhmad@uniku.ac.id
}

\begin{abstract}
Every citizen has the right in law and justice, because of that the government made Law number 16 of 2011 concerning Legal Aid to protect its citizens in the event of a disaster that befalls the community. The purpose of community service is more focused on the people or villagers, while the other objectives of this counseling are the parents who can add information related to the process of handling criminal acts and how to follow up in the event of a crime. The method used is by way of lectures and discussions then ends with questions and answers. The results obtained from this community service are more sensitive people and know how the criminal proceedings associated with brands, patents, business licenses, taxes, illegal fees, financing or financing agreements with third parties and legal assistance and response to legal issues in particular those in connection with various threats to criminal acts at this time, it is expected that with the dedication to this community, parents can become equipped in protecting their families from various possibilities related to criminal acts and legal aid.
\end{abstract}

Keywords: Legal Aid, Prevention, Socialization

\begin{abstract}
Abstrak
Setiap warga negara mempunyai hak dalam hukum dan keadilan, oleh kerana itu pemerintah membuat Undang-Undang nomor 16 Tahun 2011 tentang Bantuan Hukum untuk melindungi warganya dalam hal terjadi musibah yang menimpa masyarakat. Tujuan pengabdian kepada masyarakat ini lebih menitik beratkan kepada orang-orang atau warga desa, adapun sasaran lain yang menjadi tujuan dari diadakannnya penyuluhan ini yaitu para orang tua yang mana dapat menambah informasi terkait dengan proses penanganan tindak pidana dan bagaimana menindaklanjuti apabila terjadi tindak pidana. Metode yang digunakan yaitu dengan cara ceramah dan diskusi kemudian diakhiri dengan tanya jawab. Hasil yang diperoleh dari pengabdian kepada masyarakat ini yaitu masyarakat lebih peka dan mengetahui bagaimana proses tindak pidana yang terkait dengan merek, paten, izin usaha, pajak, pungutan liar, perjanjian pembiayaan atau pendanaan dengan pihak ketiga dan bantuan hukum serta respon terhadap permasalahan hukum khususnya yang berkaitan dengan berbagai acaman tindak pidana pada sekarang ini, diharapkan dengan adanya pengabdian kepada masyarakat ini para orang tua dapat menjadi bekal dalam menjaga keluarganya dari berbagai kemungkinan yang terkait dengan tindak pidana dan bantuan hukum.
\end{abstract}

Kata Kunci: Bantuan Hukum, Pencegahan, Sosialisasi.

\section{PENDAHULUAN}

Pasca reformasi tahun 1998 di Indonesia, salah satu agenda dalam mensejahterakan masyarakat terutama dibidang penegakan hukum sampai sekarang masih dipertanyakan. Orientasi penegakan hukum di Indonesia sendiri dititikberatkan pada pengadilan, kepolisian, kejaksaan, serta lembaga bantuan hukum baik itu pengacara ataupun lembaga bantuan hukum masyarakat, masih belum berjalan maksimal. Penegakan negara yang bersupermasi hukum menemui jalan buntu. Penegakan hukum di satu sisi dan keadilan dimasyarakat di sisi lain diperlukan keselarasan, terutama dalam hak mendapatakan bantuan hukum bagi masyarakat dengan tidak membedabedakan ras, agama, dan golongan. Sebagaimana amanah UUD 1945 terutama Pasal 27 baik yang telah diamandemen ataupun sebelum amandemen. Penjabaran UUD 1945 Pasal 27 dieterjemahkan ke dalam UU No. 16 Tahun 2011 Tentang bantuan hukum. Hukum dalam bentuknya ada dua yakni: Pertama,bersifat tidak tertulis dimana hukum yang demikian merupakan aturan hukum yang hidup dalam 
masyarakat atau yang sering dikatakan sebagai hukum adat; Kedua,hukum tertulis yakni dibuat oleh lembaga yang berwenang dan memiliki sanksi serta bersifat memaksa. Perbedaan keduannya terletak pada bentuk dan sanksinya. Bentuk hukum tidak tertulis hanya merupaka peraturan yang diturunkan secara turun temurun dan kurang memiliki sanksi yang tegas, sementara hukum tertulis selain memiliki sanksi yang tegas juga memiliki kejelasan tentang lembaga yang membuatnya. ${ }^{1}$ Sejalan dengan pendapat Soerjono Soekanto tentang penegakan hukum yang dipengaruhi oleh 5 (lima) faktor yaitu ${ }^{2}$ : Pertama: Faktor hukum dan peraturan per Undang undangan, Kedua: Faktor aparat penegak hukumnya yakni pihak pihak pihak yang terlibat dalam proses pembuatan hukumnya dan pemberlakuanya, Ketiga;Faktor sarana dan prasarana,yang mendukung proses penegakan hokum,Keempat;Faktor kesadaran masyarakat, yakni lingkungan sosial dimana hukum tersebut berlaku atau diberlakukan, Kelima; Faktor Kebudayaan yakni hasil karya, cipta dan rasa yang didasarkan pada karsa manusia didalam pergaulan hidup ${ }^{3}$. Masyarakat Kabupaten kuningan pasca reformasi merindukan program bantuan hukum gratis, harus menjadi solusi alternatif bagi masyarakat tidak mampu dalam rangka penegakan hukum agar keadilan masyarakat kuningan dalam mencapai nilai-nilai keadilan dan sekaligus menciptakan Kabupaten Kuningan ASRI. Kebutuhan bantuan hukum tersebut dapat dikatakan sebagai bentuk untuk mencegah masyarakat menjadi korban kejahatan dan menyelesaikan kasus kasus kejahatan yang terjadi sehingga masyarakat puas bahwa keadilan telah ditegakan dan yang bersalah telah di pidana. Mengusahakan agar mereka yang telah melakukan kejahatan tidak mengulangi lagi kejahatanya ${ }^{4}$ ). Semuanya diperlukan untuk mengubah paradigma bahwa hukum itu penuh dengan sanksi yang kejam dalam masyarakat di Kabupaten Kuningan. Prinsipnya bantuan hukum terbagi menjadi dua, yaitu : Litigasi dan Non litigasi diperlukan pendampingan melalui program pemerintah darah Kabupaten Kuningan.

Usaha Kecil dan Menengah (UKM) seringkali menghadapi persoalan hukum yang berkaitan dengan merek, paten, izin usaha, pajak, pungutan liar, perjanjian pembiayaan atau pendanaan dengan pihak ketiga. Selain itu, pemerintah dinilai kurang memberikan perlindungan untuk UKM yang diperparah dengan minimnya minimnya pengetahuan UKM tentang hukum. Dikatakan Humphrey, tujuan kerjasama ini adalah demi terciptanya pemahaman yang komprehensif mengenai hak dan kewajiban pelaku usaha di sektor UKM. "Agar terciptanya perlindungan hukum bagi Pelaku Usaha khususnya bagi UKM, serta adanya solusi atau problem solving terhadap permasalahan hukum yang dihadapi oleh para pelaku usaha," ujarnya dalam siaran pers. Dalam

\footnotetext{
1 Suwari Akhmaddhian dan Erga Yuhandra. 2018. "Bantuan Hukum Bagi Tenaga Pendidik Dan Kependidikan Di Desa Mancagar Kabupaten Kuningan, Indonesia". Empowerment : Jurnal Pengabdian Masyarakat, e-ISSN 2598-2052 Vol. 01 Nomor 01. 2018.72-78.

2 Suwari Akhmaddhian. Penegakan Hukum Lingkungan dan Pengaruhnya Terhadap Pertumbuhan Ekonomi di Indonesia (Studi Kebakaran Hutan Tahun 2015). Jurnal Unifikasi, ISSN 2354-5976 Vol. 03 Nomor 01 Januari 2016.

${ }^{3}$ Soerjono Soekanto, Bantuan Hukum Suatu tinjauan Sosio-Yuridis, Ghalia Indah,Jakarta, 1983, hlm.15.

${ }^{4}$ Romli Atmasasmita, Sistem Peradilan Pidan Kontemporer , Jakarta: Kencana, 2011, hlm 3.
} 
kerjasama ini, ditegaskan Humphrey, AAI dan KADIN sama-sama berkomitmen untuk tidak melakukan suap terhadap berbagai pihak yang terkait. "Kita akan menyelesaikan segala sesuatunya dengan cara profesional dan di jalur yang benar, dan semua pengeluaran yang dilakukan harus bersifat transparan dan akuntabel, serta semua kegiatan harus dilaporkan dan bersifat terbuka."5

\section{METODE PELAKSANAAN}

Dalam melaksanakan Pengabdian Kepada Masyarakat ini selaku pemateri saya memberikan pemaparan dalam bentuk power point agar masyarakat dapat memperhatikan dengan lebih cermat, serta menambahkan berbagai gambar-gambar sebagai contoh dari tema yang akan dibahas sehingga mereka lebih memahami akan realita yang sebenarnya. Metode yang digunakan dalam Pengabdian Kepada Masyarakat ini melalui metode ceramah dan diskusi dan tanya jawab, dengan tanya jawab ini masyarakat diberikan kesempatan untuk bertanya sesuai dengan tema penyuluhan, atau masyarakat dapat bertanya di luar tema yang telah ditentukan.

Sasaran kegiatan pengabdian masyarakat ini dilakukan dengan harapan perubahan prilaku sosial yang ada di masyarakat dengan melakukan penyuluhan dengan sasaran yang menjadi tujuan pengabdian ini lebih menitik beratkan kepada yaitu para orang tua yang mana memiliki anak yang harus dijaga dan dilindungi. Lokasi Pengabdian Kepada Masyarakat ini dilakukan tepatnya di Desa Mandapajaya Kabupaten Kuningan pada Bulan Agustus 2019.

\section{HASIL DAN PEMBAHASAN}

Pengaturan bantuan hukum bagi masyarakat berkaitan dengan penelitian sehingga terdapat kerangka teoritis dan kerangka konseptual. Kerangka teoritis merupakan kerangka dimana masalah di ambil atau di hubungkan ${ }^{6}$. Pada umumnya kerangka teoritis disajikan dalam bentuk proposisi atau pernyataan yang salung berkaitan dan bertujuan memberikan gambaran yang sistematis tentang suatu gejala dan selanjutnya dapat membantu kasusu-kasus konkrit yang lebih adil, teori dalam penelitian mempunyai fungsi untuk mengarahkan kepada peneliti apa yang harus dilakukan. Kerangka konseptual adalah kerangka yang lebih menggambarkan hubungan antara konsepkonsep khusus yang melandasi penelitian. Kerangka konseptual lebih mengedapankan definisi-definisi dari suatu permasalahan dengan kata lain konsep merupakan urian-uraian mengenai hubungan-hubungan dalam fakta tersebut. Berdasarkan penjelasan diatas maka peneliti dapat memberikan gambaran teoritis dalam penelitian ini sebagai berikut : Implementasi menurut kadir adalah kegiatan yang dilakukan untuk menguji data dan menerapkan system yang diperoleh dari kegiatan seleksi.3 Jadi dapat disimpulkan bahwa implementasi merupakan proses untuk menguji

5 https://www.hukumonline.com/berita/baca/lt506c578d3d29c/aai-dan-kadin-teken-

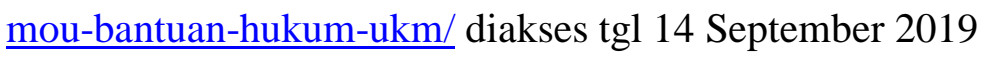

\footnotetext{
${ }^{6}$ Soerjono Soekanto, Bantuan Hukum Suatu tinjauan Sosio-Yuridis, Ghalia Indah,Jakarta, 1983 , hlm.34.
} 
antara konsep dengan konseptual atau antara tex dan kontek. Selanjtnya menurut fullan implenetasi adalah suatu proses untuk melaksanakan ide, program atau seperangkat aktifitas baru dengan harapan orang lain dapat menerima dan melakukan perubahan. Beradasarkan pengertian diatas dapat di simpulakan bahwa implentasi adalah suatu proses untuk menilai, mengevaluasi dan mengukur apakah suatu peraturan atau kebijakan dapat berjalan dengan baik atau tidak, dengan begitu maka akan di nilai apakah harus ada evaluasi atau tidak terhadap program tersebut.

Bantuan Hukum Beberapa definisi tentang bantuan hukum adalah sebagai berikut ${ }^{7}$ :

1. Menurut Roberto Conception bantuan hukum adalah pengungkapan yang umum yang digunakan untuk menunjuk kepada setiap pelayanan hukum yang ditawarkan atau diberikan. Ini terdiri dari pemberian informasi atau pendapat mengenai hakhak, tanggung jawab dalam situasi tertentu, sengketa, litigasi atau proses hukum yang dapat berupa peradilan, semi peradilan atau yang lainnya.

2. Menurut C.A.J Crulbantuan Hukum merupakan bantuan yang diberikan oleh para ahli kepada mereka yang memerlukan perwujudan atau realisasi dari hak-haknya serta memperoleh perlindungan hukum.

3. Menurut UU No 16 Tahun 2011 tentang Bantuan Hukum disebutkan bahwa Bantuan Hukum adalah jasa hukum yang diberikan oleh Pemberi Bantuan Hukum secara cumacuma kepada Penerima Bantuan Hukum.

4. UU No. 18 Tahun 2003 tentang Advokat menjelaskan yaitu Bantuan hukum adalah jasa yang diberikan oleh advokat secara cuma-cuma kepada klien yang tidak mampu.

Pelaksanaan bantuan hukum harus seiring dengan nafas yang menjadi tujuanya adalah perlindungan hak asasi manusia dan cita cita keadilan jangan sampai menjadi kegiatan yang tidak berarti, hal ini seperti apa yang menjadi kritik dari Todung Mulya Lubis yang melakukan kritik terhadap bentuk bantuan hukum yang bersifat tradisional dan individual dengan mengemukakan sejumlah kelemahannya yaitu ${ }^{8}$ :

1. Bantuan hukum yang bersifat tradisional dan individual hanya bersifat "mengobati" tetapi tidak mencari dan menyembuhkan penyebab penyakit tersebut dimana masyarakat sebelumnya telah diasingkan dari hak-haknya sendiri.

2. Sistem hukum yang ada masih menunjang bentuk-bentuk bantuan hukum tradisional dan individual, dimana proses penyelesaian hukum masih berkisar pada pengadilan dan proses beracara yang ada didalamnya.

3. Bersifat kekotaan, karena para ahli hukum yang menyediakan layanan bantuan hukum ada di perkotaan dan tidak mudah dijangkau oleh masyarakat perdesaan dan wilayahwilayah yang sulit dijangkau.

4. Sifatnya pasif, menunggu masyarakat miskin menyadari hak-haknya dan mengklaimnya.

\footnotetext{
${ }^{7}$ Diding Rahmat. Implementasi Kebijakan Program Bantuan Hukum Bagi Masyarakat Tidak Mampu di Kabupaten Kuningan. ISSN 2354-5976 Vol. 04 Nomor 01 Januari 2014, hlm. 35-42

${ }^{8}$ Todung Mulya Lubis, 1983,Bantuan Hukum dan Kemiskinan Struktural, Jakarta: Cendana Press, hal 1-3
} 
5. Terlalu terikat pendekatan-pendekatan hukum, bukan bagaimana membantu penyelesaian secara cepat atau mengatasi konflik.

6. Masih berjalan sendiri, tidak bekerjasama dengan organisasi bantuan hukum, padahal organisasi bantuan hukum dianggap paling cepat menyelesaikan konflik.

7. Belum mengarah pada terciptanya gerakan sosial, dimana gerakan bantuan hukum dikaitkan dengan power resources sehingga posisi masyarakat akan lebih kuat dan mempercepat penyelesaian konflik pusat pinggiran. Berdasarkan urain diatas maka dapat disimpulkan bahwa bantuan hukum merupakan jasa hukum baik litigasi dan non litigasi yang diberikan secara Cuma Cuma kepada masyarakat yang dilakukan oleh orang propesional seperti advokat atau pengacara guna mendapingi hak hak masyarakat yang membutuhkan jasa bantuan hukum.

Masyarakat secara umum ataupun masyarakat yang tidak mampu atau miskin masyarakat miskin adalah pengecualian dari hukum yang menurut mereka seringkali tidak adil dan menutup kesempatan mereka untuk meningkatkan taraf hidup mereka dan ini terjadi di hampir kebanyakan negara berkembang dan miskin di dunia. Mereka bekerja tidak dalam koridor hukum tetapi di luar hukum itu sendiri: buruh yang bekerja tanpa kontrak, usaha yang tidak terdaftar dan mendiami tanah tanpa dokumen legal. Karena itulah, mereka menjadi pihak yang paling rentan untuk dikategorikan sebagai pelanggar hukum dan sekaligus tidak mendapatkan bantuan apapun dari negara ketika haknya dilanggar.Secara harfiah, kemiskinan berasal dari kata dasar miskin yang artinya tidak berharta-benda 9 . Dalam pengertian yang lebih luas, kemiskinan dapat dikonotasikan sebagai suatu kondisi ketidakmampuan baik secara individu, keluarga, maupun kelompok sehingga kondisi ini rentan terhadap timbulnya permasalahan sosial yang lain. Kemiskinan dipandang sebagai kondisi seseorang atau sekelompok orang, laki-laki dan perempuan yang tidak terpenuhi hak-hak dasarnya secara layak untuk menempuh dan mengembangkan kehidupan yang bermartabat. Dengan demikian, kemiskinan tidak lagi dipahami hanya sebatas ketidak mampuan ekonomi, tetapi juga kegagalan pemenuhan hakhak dasar dan perbedaan perlakuan bagi seseorang atau sekelompok orang, dalam menjalani kehidupan secara bermartabat. Hidup miskin bukan hanya berarti hidup di dalam kondisi kekurangan sandang pangan, dan papan. Akan tetapi, kemiskinan juga berarti akses yang rendah dalam sumber daya dan aset produktif untuk memperoleh kebutuhankebutuhan hidup, antara lain: ilmu pengetahuan, informasi, teknologi, dan modal. Sehingga dengan kenyataan seperti itu membuat tidak berdaya dan oleh karenanya rentang mendapatkan perlakukan yang baik dalam segala hal.cMaka oleh karena itu peru adanya system jaminan Sosial termasuk hukum dalam rangka melindungi hak hak dan kepentinganya secara ekonomi, hukum, budaya dan lain sebagainya. Bantuan hukum bagi pelaku usaha merupakan bentuk edukasi terkait dengan peningkatan pengetahuan masyarakat terkait dengan merek, paten, izin usaha, pajak, pungutan liar, perjanjian pembiayaan atau pendanaan dengan pihak ketiga.

\footnotetext{
${ }^{9}$ Abdurahman, Aspek-aspek Bantuan Hukum di Indonesia, Cendana Press,Jakarta,1983,hlm.54.
} 


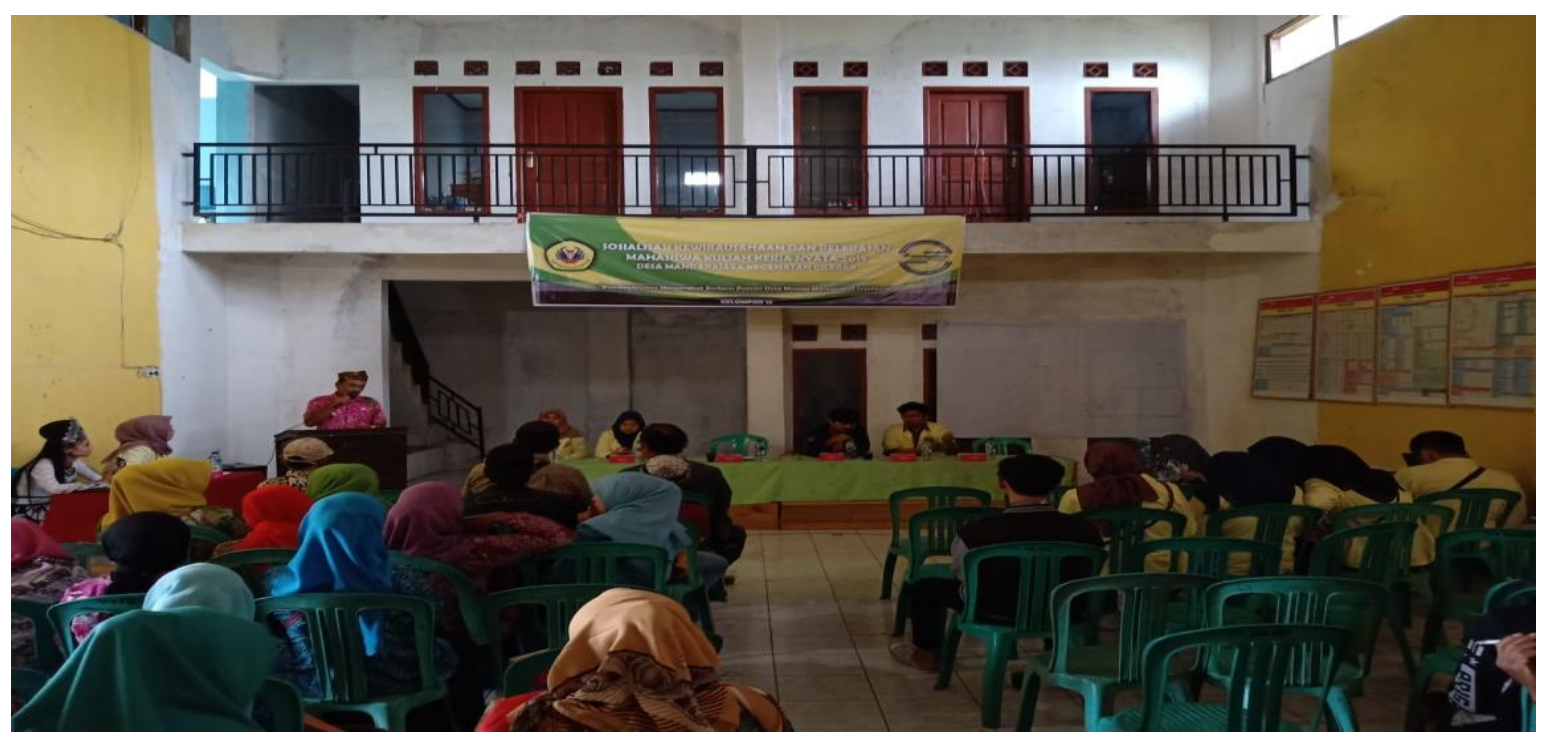

Gb.01. Kegiatan Penyuluhan Hukum di Desa Mandapajaya

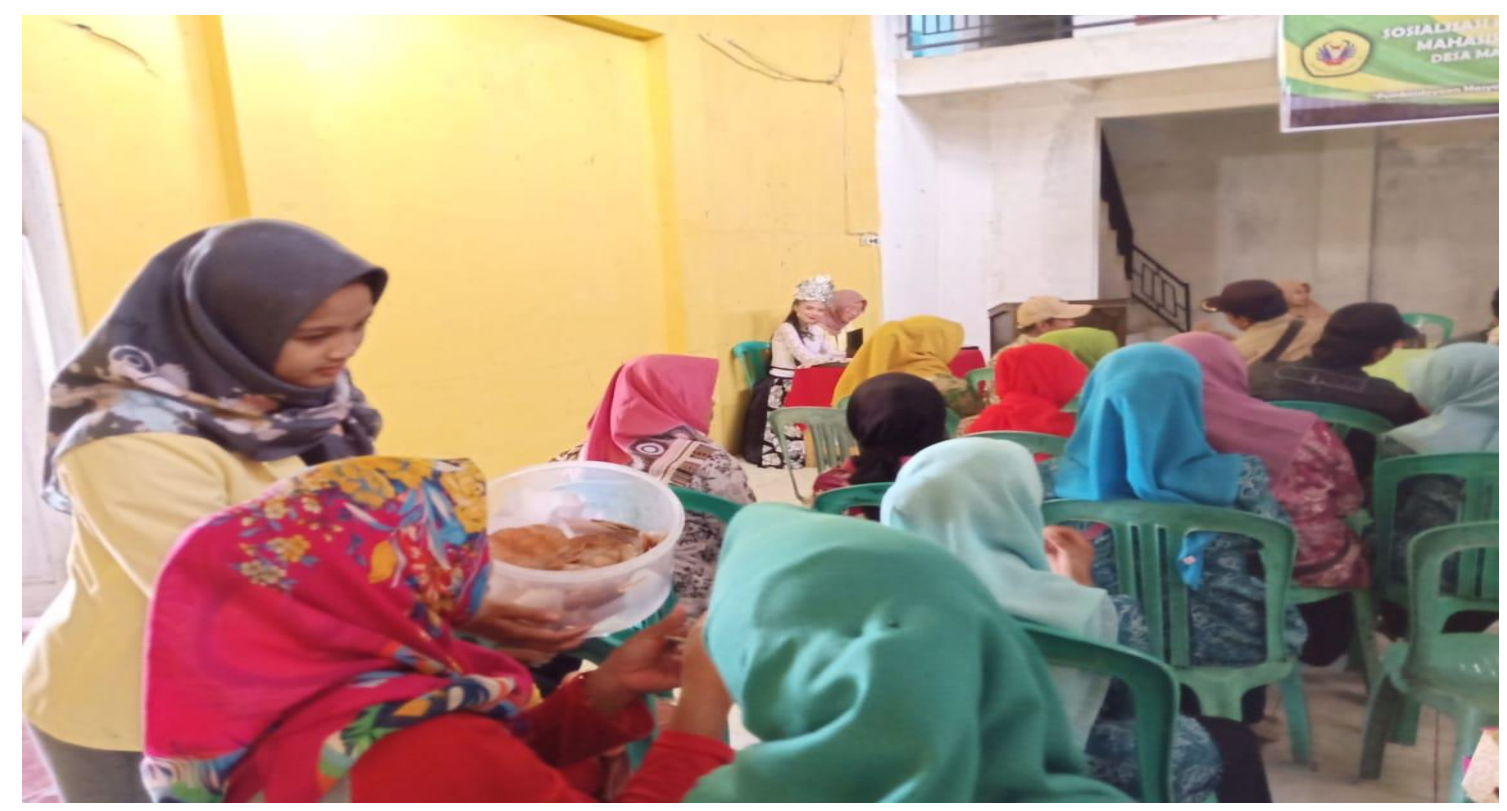

Gb.02. Kegiatan Penyuluhan Hukum di Desa Mandapajaya

\section{SIMPULAN}

Hasil yang diperoleh dari pengabdian kepada masyarakat ini yaitu masyarakat lebih peka terhadap permasalahan hukum khususnya yang berkaitan dengan hukum pidana seperti jaman sekarang ini, diharapkan dengan adanya pengabdian kepada masyarakat ini para orang tua khususnya yang memiliki anak umur remaja lebih memperhatikan dan lebih mengawasi kegiatan-kegiatan yang dianggap menyimpang. Dengan kegiatan ini pemahaman tentang hukum masyarakat menjadi meningkat dan sangat antusias dengan kegiatan pengabdian tersebut. Tentang kegiatan ini saya merekomendasikan agar kegiatan pengabdian kepada masyarakat perlu ada upaya antara 
Uniku berkerja sama dengan pemerintahan desa supaya kegiatan pengabdian ini optimal dan dapat dilakukan secara berjangka, sehingga peran serta masyarakat lebih antusias.

\section{SARAN}

Peningkatan kualitas pelaku usaha kecil menengah sangat diperlukan pengetahuan tentang perlindungan hukum terkait usahanya, sehingga perlu adanya pelatihan-pelatihan atau penyuluhan terkait dengan standar-standar izin suatu usaha.

\section{UCAPAN TERIMA KASIH}

Penulis ucapkan terima kasih kepada Ketua Pusat Konsultasi dan Bantuan Hukum FH UNIKU, Dekan FH UNIKU, Rektor Universitas Kuningan, Pemerintah Daerah Kabupaten Kuningan serta Badan Pembinaan Hukum Nasional (BPHN) Kementerian Hukum dan HAM RI atas segala dukungan yang telah diberikan sehingga terselenggaranya kegiatan pengabdian ini.

\section{DAFTAR PUSTAKA}

Abdurahman. 1983. Aspek-aspek Bantuan Hukum di Indonesia, Cendana Press. Jakarta. Diding Rahmat. 2014. Implementasi Kebijakan Program Bantuan Hukum Bagi Masyarakat Tidak Mampu di Kabupaten Kuningan. Jurnal Unifikasi . Vol. 04 Nomor 01 Januari 2014, hlm. 35-42.

Romli Atmasasmita. 2011. Sistem Peradilan Pidan Kontemporer, Jakarta: Kencana.

Roni Nursyamsu. 2018. Pelatihan Peningkatan Kapasitas Pemuda Dan Pembuatan Program Kerja Pada Organisasi Pemuda Desa Cibinuang, Kabupaten Kuningan, Empowerment : Jurnal Pengabdian Masyarakat, E-Issn 2598-2052

Soerjono Soekanto. 1083. Penegakan Hukum.cet. 2007, BPHN7 Binacipta, Jakarta.

Soerjono Soekanto. 1983. Bantuan Hukum Suatu tinjauan Sosio-Yuridis, Ghalia Indah. Jakarta.

Suwari Akhmaddhian. 2016. Penegakan Hukum Lingkungan dan Pengaruhnya Terhadap Pertumbuhan Ekonomi di Indonesia (Studi Kebakaran Hutan Tahun 2015). Jurnal Unifikasi. Vol. 03 Nomor 01 Januari 2016.

Suwari Akhmaddhian dan Erga Yuhandra. 2018. "Bantuan Hukum bagi Tenaga Pendidik dan Kependidikan di Desa Mancagar Kabupaten Kuningan, Indonesia". Empowerment : Jurnal Pengabdian Masyarakat, e-ISSN 2598-2052 Vol. 01 Nomor 01. 2018.72-78.

Todung Mulya Lubis, Bantuan Hukum dan Kemiskinan Struktural, Jakarta: Cendana Press. 1983.

https://www.hukumonline.com/berita/baca/lt506c578d3d29c/aai-dan-kadin-teken-moubantuan-hukum-ukm/ diakses tgl 14 September 2019 